\title{
FLOOD ASSESSMENT STUDY IN THE CITY OF TANGERANG, WEST
}

\author{
JAVA \\ Acep Hidayat. \\ Faculty of Engineering, University Mercu Buana, Indonesia \\ E-Mail:acephidayat1975@gmal.com
}

\begin{abstract}
Tangerang city is a region which has a relatively flat and inclined contour-shaped basin so that in some areas when the rains come will experience flooding. The cause of the flooding is necessary to identify the field. From the results obtained that the identification of flood discharge for the region amounted to $29.91 \mathrm{~m}^{3}$ / s with $1.65 \mathrm{~km}^{2}$.Dari watershed area of this discharge can only be accommodated by the existing drainage network is only $5 \mathrm{~m}^{3}$ / sec so that the excess is what makes this region flood. For excess of $24.91 \mathrm{~m}^{3} / \mathrm{s}$ is done by creating a polder or ponds so that these advantages can be accommodated. Polder or ponds that can accommodate this excess area of 6.3 hectares with a depth of 4 meters. In addition to planning embung / Polder required also increase drainage infrastructure sehigga can flow smoothly.
\end{abstract}

Keywords: Flood discharge, Embung / Polder.

\section{INTRODUCTION}

Flooding is a popular word among Tangerang City Government, particularly in the rainy season. Flooding in the city of Tangerang influenced by several things, including natural factors such as the characteristics of a river with a small river channel capacity, the rising tide of sea water that block the flow of rivers, as well as topography is relatively flat so that about $40 \%$ of the area of Tangerang City is a flood plain

As a result of runoff increases. Land use change from the open area into the area awoke also increase erosion. Erosion material carried along into the water channel, time, and resulted in the silting of reservoirs and constriction.

Based on the above, it would require a treatment program (control) by planning the manufacture of reservoir. The planning of the expected flow of rain water can be optimally accommodated in the reservoir which is in accordance with its capacity.

\section{METHODOLOGY.}

Average rainfall can be calculated by the approximate formula:

Where:

$\mathrm{Hi}=$ rain at each station $\mathrm{i}(1,2, \ldots ., \mathrm{N}$ in the area under review).

$\mathrm{N}=$ number of stations,

$\mathrm{RH}=$ average rain
Note that to calculate the rain region by adopting an average of algebra, rainfall data were reviewed and taken into account is the rainfall data inside the basin (catchment area) in this case $H 1, H 2, \ldots ., H \neg n$. Which are outside the area of the flow is not calculated.

\section{Analysis of Maximum Daily Rainfall and Flooding Debit}

Determination of maximum precipitation with a specific return period can be calculated using frequency analysis methods. Several well-known methods such as Method Log-Pearson Type III, Haspers, and Gumbel. The method used will be determined by looking at the characteristics of the local area rainfall distribution. Return period will be calculated for each method is repeated for a period of 2, 5, 10, 25, 50, and 100 years. As the examples below are presented the calculation method based on Gumbel.

\section{Frequency distribution Gumbel.}

Gumbel distribution method is widely used in the analysis of the frequency of rain that has formula

$\mathrm{Rt}=\mathrm{R}+\mathrm{K} . \mathrm{Sx}$

$\mathrm{K}=(\mathrm{yt}-\mathrm{yn}) / \mathrm{Sn}$.

$\mathrm{Yt}=-(0834+2303 \log \mathrm{T} / \mathrm{T}-1)$

Where:

$\mathrm{Rt}=$ Rainfall for year return period $\mathrm{T}(\mathrm{mm})$.

$\mathrm{R}=$ maximum rainfall average.

$\mathrm{Sx}=$ standard deviation. 
Khe 2nactor frequency. With the reservoir is expected to be able to drain the
2016

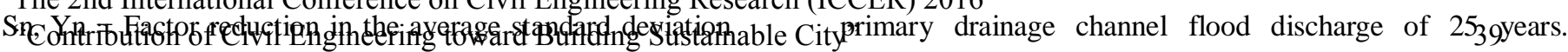
as a function of the amount of data.

\section{Debit calculation Flood}

In planning the maximum discharge in a channel which involves hydrological therein, often encountered estimate the flood peak is calculated by a simple and practical method, in which the calculation technique by inserting a factor of rainfall, physical state and nature of the hydraulics flow area. Determination of flood discharge plan, made in accordance with the Procedures for Flood Discharge Calculation Plan, SNI. Determination of flood discharge can be done in two (2) ways, namely Rational Method or Method Unit hydrograph (Synthetic hydrograph).

\section{Metode Rasional}

Procedures rational use of the formula method. Rational use of the formula method procedure is given in the figure below. The following points should be noted:

There are four components of this formula which must be obtained magnitude.

- Look for a unit intensity of the rain, when the intensity in liters / detik.ha, and streams in the area ha, it will obtain the discharge in liters / sec.

- If the intensity in $\mathrm{mm} / \mathrm{h}$, then it should be first converted into units of liters / detik.ha (multiply by 2.78).

\section{Analysis Calculation}

Resume Calculation Frequency Distribution Analysis

\begin{tabular}{|c|c|c|c|c|}
\hline \multirow{2}{*}{$\begin{array}{c}\text { Periode } \\
\text { Ulang }\end{array}$} & \multicolumn{4}{|c|}{ Metode } \\
\hline & Normal & Log Normal & $\begin{array}{c}\text { Log Person } \\
\text { Type III }\end{array}$ & Gumbel \\
\hline 2 & 130.513 & 129.916 & 127.272 & 129.238 \\
\hline & 140.629 & 140.414 & 139.005 & 144.831 \\
\hline & 145.927 & 146.262 & 147.547 & $15 \overline{5} .153$ \\
\hline & 151.081 & 151.283 & 158.952 & 168.200 \\
\hline & 155.200 & 157.163 & 167.825 & 177.877 \\
\hline$\overline{100}$ & 158.572 & $161 . \overline{2} 2 \overline{8}$ & 176.969 & 187.482 \\
\hline
\end{tabular}

\begin{tabular}{|c|c|c|c|}
\hline \multirow{2}{*}{$\begin{array}{c}\text { Periode } \\
\text { Ulang }\end{array}$} & \multirow{2}{*}{$\begin{array}{c}\text { Hujan Rencana } \\
\mathbf{R}_{24}\end{array}$} & \multicolumn{2}{|c|}{ Debit Banjir Rencana $\left(\mathrm{m}^{3} / \mathrm{dt}\right)$} \\
\hline & & Metode & Metode \\
\hline (tahun) & $(\mathrm{mm})$ & Rasional & Haspers \\
\hline 2 & 127.272 & 23.952 & 25.162 \\
\hline 5 & 139.005 & 26.160 & 27.481 \\
\hline 10 & 147.547 & 27.767 & 29.170 \\
\hline 25 & 158.952 & 29.914 & 31.425 \\
\hline 50 & 167.825 & 31.584 & 33.179 \\
\hline 100 & 176.969 & 33.304 & 34.986 \\
\hline
\end{tabular}

the steady flow analysis. Here layout plan.

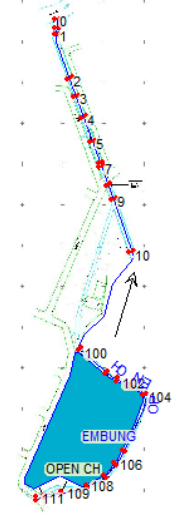

\section{Gambar VI.1 Layout Polder}

Debit Perum Pondok Arum will be added to the watershed discharge Cimone. The amount of discharge is added to the primary drainage channel adapted to the capacity of the channel so that the excess will be accommodated by the reservoir. On this model, the channel capacity is still able to accommodate the additional discharge Cimone watershed of $5 \mathrm{~m} 3$ / s, so that the excess flow of $24.91 \mathrm{~m} 3$ / $\mathrm{s}$ will be accommodated by the reservoir (Q25 DAS Cimone = $29.91 \mathrm{m3} \mathrm{/} \mathrm{s})$. 


\section{C alculation of flood discharge plan Rational Method}

\begin{tabular}{|c|c|c|c|c|c|c|c|c|c|}
\hline $\begin{array}{c}\text { Periode } \\
\mathrm{T} \\
(\text { tahm) }\end{array}$ & $\mathrm{A}\left(\mathrm{km}^{2}\right)$ & $\begin{array}{c}\mathrm{R}_{24} \\
(\mathrm{~mm})\end{array}$ & $\begin{array}{c}\mathrm{L} \\
(\mathrm{km})\end{array}$ & $\begin{array}{c}\mathrm{H} \\
(\mathrm{km})\end{array}$ & $\mathrm{C}$ & $\begin{array}{c}\pi \\
(\mathrm{kmjam})\end{array}$ & $\begin{array}{c}\mathrm{t} \\
(\mathrm{jm})\end{array}$ & $\begin{array}{c}\mathrm{I} \\
(\mathrm{mm} j \mathrm{jm})\end{array}$ & $\mathrm{Qt}\left(\mathrm{m}^{\mathrm{m} / \mathrm{dt})}\right.$ \\
\hline 2 & 3.790 & 1.27 .272 & 3.430 & 0.010 & 0.70 & 2.168 & 1.582 & 32.502 & 23.952 \\
\hline 5 & 3.790 & 139.005 & 3.430 & 0.010 & 0.70 & 2.168 & 1.582 & 35.498 & 26.160 \\
\hline 10 & 3.790 & 1.47 .547 & 3.430 & 0.010 & 0.70 & 2.168 & 1.582 & 37.679 & 27.767 \\
\hline 25 & 3.790 & 158.952 & 3.430 & 0.010 & 0.70 & 2.168 & 1.582 & 40.592 & 29.914 \\
\hline 50 & 3.790 & 167.825 & 3.430 & 0.010 & 0.70 & 2.168 & 1.582 & 42.558 & 31.584 \\
\hline 100 & 3.790 & 176.969 & 3.430 & 0.010 & 0.70 & 2.168 & 1.582 & 45.193 & 33.304 \\
\hline
\end{tabular}

\section{Method of calculation of flood discharge plan Haspers}

\begin{tabular}{|c|c|c|c|c|c|c|c|c|}
\hline \multirow{2}{*}{\begin{tabular}{|l} 
Periode \\
Ulang \\
\end{tabular}} & ujan Rencen & Luas DAS & Durasi hujan & Distribusi hujan & Debit tiap Km & \multirow{3}{*}{ a } & \multirow{3}{*}{$\beta$} & \multirow{3}{*}{$\begin{array}{l}Q t \\
\left(\mathrm{~m}^{3} / \mathrm{dt}\right)\end{array}$} \\
\hline & $\mathbf{R}_{24}$ & $A$ & $t$ & Rn & 9 & & & \\
\hline (tahlu) & (mim) & $\mathrm{Km}^{2}$ & (jim) & (mim) & $\left(\mathrm{m}^{3} / \mathrm{km} / \mathrm{dt}\right)$ & & & \\
\hline 2 & 127.272 & 3.790 & 0.897 & 60.172 & 18.639 & 0.866 & 0.412 & 25.162 \\
\hline 5 & 139.005 & 3.79 & 0.897 & 65.719 & 20.357 & 0.866 & 0.412 & 27.481 \\
\hline 10 & 147.547 & 3.79 & 0.897 & 69.757 & 21.608 & 0.866 & 0.412 & 29.170 \\
\hline 25 & 158952 & 3.79 & 0.897 & 75.150 & 23.279 & 0.866 & 0.412 & 31.425 \\
\hline 50 & 167.825 & 3.79 & 0.897 & 79.345 & 24.578 & 0.866 & 0.412 & 33.179 \\
\hline 100 & 176.969 & 3.79 & 0.897 & 83.667 & 25.917 & 0.866 & 0.412 & 34.986 \\
\hline
\end{tabular}

This scenario will be performed on the stages of the design as follows:

a) hydrograph discharge into the reservoir together with scenario 3 amounted to $24.91 \mathrm{~m} 3$ / s.

b) Inlet reservoir is next to the spillway and outlet $B=10 \mathrm{~m}$ water reservoir door dimensions are $0.5 \times 0.5 \mathrm{~m}(\mathrm{BxH})$ and 4 units of the pump.

c) The depth of the reservoir is $4 \mathrm{~m}$, with consideration of the level of security for areas outside the reservoir is a settlement.

\section{RESULTS AND DISCUSSION}

From the results of modeling of flood water surface profile, it can be concluded:

1. The cause of flooding in Perum Pondok Arum, including:

a. Culverts are not able to accommodate the discharge of a cottage complex Arum and Cimone.

b. Wet cross-sectional area small bridge into a bottle neck stream, causing backwater.

Solution Perum Pondok flooding in Arum: c. Culverts will not be used again, because the sewer lines will be created ponds.

d. Primary drainage channel which will pass through the back of the Posyandu. New paths of STA 101 STA 8 with the type of open channel dimensions $3 \times 2.5 \mathrm{~m}(\mathrm{BxH})$, the channel length of $150 \mathrm{~m}$, and the channel bottom slope 0:23\%.

e. Widening the wet cross-sectional area of the bridge, by reducing the thick bridge deck. Wet crosssection of the existing bridge $3 \times 0.7 \mathrm{~m}(\mathrm{BxH})$, bridge design 3x2m (BxH).

f. By implementing the solution of flooding on points a - c, complex drainage channel capacity cottage Arum only can stream discharge from watersheds and watershed Cimone cottage Arum for $5 \mathrm{~m} 3 / \mathrm{s}$. So there are excess flow $24.9 \mathrm{~m} 3 / \mathrm{s}$ that can not be drained by drainage channels.

g. To accommodate the excess discharge of $24.9 \mathrm{~m} 3 /$ $\mathrm{s}$, it will be planned two scenarios, ie with and without the pump flood pump flood.

h. If using reservoir outlet orifice door dimensions $1 \mathrm{x} 1 \mathrm{~m}(\mathrm{BxH})$. So that the required storage capacity is $178.100 \mathrm{~m} 3$ with spacious pool $6.3 \mathrm{Ha}$ and reservoir depth of $4 \mathrm{~m}$. Because the reservoir is $0.3 \mathrm{Ha}$ land availability, so the shortage of land for dam location is 6HA.

i. If using reservoir outlet orifice door dimensions $0.5 \times 0.5 \mathrm{~m}(\mathrm{BxH}), 2$ units per pump station with a capacity of $2 \mathrm{~m} 3 / \mathrm{s}$, and 2 units per pump station with a capacity of $1 \mathrm{~m} 3 / \mathrm{s}$. So that the required storage capacity is $116.000 \mathrm{~m} 3$ with spacious pool 4.1Ha and reservoir depth of $4 \mathrm{~m}$. Because the reservoir is $0.3 \mathrm{Ha}$ land availability, so the shortage of land for dam location is $3.8 \mathrm{Ha}$.

2. In this work, time Sabi not go into design planning restrictions so it is not done modeling of flood water surface profile in Kali Sabi. So the flood water level in Kali Sabi (downstream drainage channels) are assumed to be able to accommodate the discharge of a cottage complex Cimone if Arum and watershed planning Sabi normalization has been carried out. Due to the normalization Sabi planning would have take into account the DAS cottage Arum and Cimone.

\section{Referensi}


The 2nd International Conference on Civil Engineering Research (ICCER) 2016

"Contribution of Civil Engineering toward Building Sustainable City"

1. Arifjaya, N.M. 2002. Hutan dan Pencegahan Banjir. Makalah SeminarDisampaikan dalam Diskusi Panel Upaya

2. Penanggulangan Banjir diJabotabek pada Tanggal 7 Maret 2002 di IPB Bogor.Asdak, C. 1995.

3. Hidrologi dan Pengelolaan Daerah Aliran Sungai. Gadjah MadaUniversity Press. Yogyakarta.

4. Balai Rehabilitasi Lahan dan Konservasi Tanah (BRLKT) Citarum-Ciliwung.2002.

5. Identifikasi Banjir dan Genangan di Wilayah Jabotabek. Bogor. 